\title{
SYNTHESIS OF ZEOLITES CANCRINITE AND \\ CHABAZITE USING PARTIAL DE-ALUMINATED \\ KAOLIN
}

Taha M. A. Razek ${ }^{(1)}$; Abdullah, N. A. ${ }^{(2)}$ and Ahmed, E. A.

1) Dept. of Env., Basic Sciences, Institute of Env., Studies and Research, Ain Shams University 2) Dept. of Research and Development, Aluminum Sulphate Company of Egypt

\begin{abstract}
Waste resulted from aluminum sulfate industry can be used as a source of silicate and aluminum. Such waste is called partial de-aluminated kaolin which is a solid waste. This work aims at utilizing such waste in the synthesis of some zeolites, Cancrinite and Chabazite-Na as two members of zeolite family were synthesized from It has been used as source of silica and alumina. Alumina ratio can be adjusted by adding aluminum sulfate. Cancrinite and Chabazite-Na were synthesized by heating partial dealuminate kaolin for $2 \mathrm{~h}$ at $130{ }^{\circ} \mathrm{C}$ in autoclave. The hydrothermal system took 6-8 hours. However, 36 hours ageing at $70{ }^{\circ} \mathrm{C}$ was found to be synthesized Cancrinite and Chabazite-Na. The products were characterized using XRD and Sem .

Key words: kaolin, Cancrinite, Chabazite, partial de-aluminate kaolin, XRD, Sem, aluminum sulfate, autoclave, silica, alumina.

\section{INTRODUCTION}

Zeolites are crystalline, microporous, hydrated alumino-silicates of alkaline or alkaline earth. The frameworks are composed of $\left[\mathrm{SiO}_{4}\right]^{4-}$ and $\left[\mathrm{AlO}_{4}\right]^{5-}$ metals tetrahedral, which corner-share to form different open structures. Negative charge of lattice is compensated by the positive charge of cations located at specific positions of zeolite framework (Bekkum et al.,
\end{abstract}


1991 and Breck, 1974). In most of zeolites the compensating cations are usually mono- and divalent metal ions and/or their combinations (Engelhardt and Michel, 1987, Takaishi et al., 1995 and Earl and Deem, 2006). In accordance with the Lowenstein's rule (Loewenstein, 1954), Al-O-Al bonds do not exist in aluminosilicate frameworks of zeolite. Instead of the tetrahedral bonded atoms $\mathrm{Si}$ and $\mathrm{Al}$, so-called "T-atoms", others such as $\mathrm{P}$, $\mathrm{Ga}, \mathrm{Ge}, \mathrm{B}, \mathrm{Be}$, etc. can exist in the framework as well (Takaishi et al., 1995, McCusker and Baerlocher, 2001 ). The synthesis of zeolites in forms suitable for industrial applications is of great importance. Barrer's pioneering work in 1948 demonstrated that a wide range of zeolites could be synthesized from aluminosilicate gels (Barrer, 1948). At present, synthetic zeolites are used commercially more often than natural zeolites due to the purity of crystalline products and the uniformity of particle sizes (Breck, 1974 and Szoztak, 1998). However, the preparation of synthetic zeolites from chemical sources of silica and alumina is expensive. Such costs may be reduced by the use of clay minerals, volcanic glasses (perlite and pumice)(Saija et al., 1983), rice husks ash , diatoms, fly ash or paper sludge ash as starting materials(Querol et al., 1997, Adamczyk and Bialecka, 2005, , Tanaka et al., 2004, Walek et al., 2008 and Wang et al., 2008). zeolite has also been developed by the transformation of one zeolite type into other zeolite types (Rios et al., 2007 and Sandoval et al., 2009). Zeolites synthesis involves the hydrothermal crystallization of alumino-silicate gels (formed upon mixing an aluminate and silica solution in the presence of alkali hydroxides and/or organic bases), or solutions in a basic environment. The crystallization is in a closed 
hydrothermal system at increasing temperature, autogenously pressure and varying time (few hours to several days)( Georgiev et al., 2011). The use of waste materials in zeolite synthesis contributes to the mitigation of environmental problems, generally in the field of water purification, removing heavy metals or ammonia, and turns them into attractive and useful products. In the present study we used partial de-aluminated kaolin (PDAK) to synthesize cancrinite and chabazite. PDAK is the solid waste resulted in aluminum sulphate industry. Considerable quantities of this waste material, about 150 ton per day. The major constituent of the waste is silica. Kaolin is a local ore mined in south Sinai. Kaolin is initially calcined at $750{ }^{\circ} \mathrm{C}$ for one hour to be converted to the reactive phase "meta-kaolin" before partial dealumination. partial de-alumination of meta-kaolin is done by leaching out the structural alumina with sulphuric acid. PDAK contains the basic ingredients needed for the manufacturing of zeolites such as silica and alumina. The ratio of silica / alumina can be modified by adding either silica or alumina.

Chabazite is a small pore size zeolite (dehydrated chabazite has apertures of $0.38 \mathrm{~nm}$ ), with a $\mathrm{Si} / \mathrm{Al}$ ratio of around 2. As anticipated from its high Al content, chabazite is hydrophilic. The aluminosilicate framework of chabazite consists of D6R units (double hexagonal rings) arranged in layers in the sequence of $\mathrm{ABCABC}$ (Breck, 1974). Cation exchange properties of chabazite have been extensively studied (Dyer, and Zubair, 1998). Chabazite has also been used as shape selective catalysts for ethyl amine synthesis (Ilao, et al.,1996). 
J. Environ. Sci.

Institute of Environmental Studies and Research - Ain Shams University

Cancrinite-group minerals are framework aluminosilicates (feldspathoids) characterized by a network of ( $\mathrm{Al}, \mathrm{Si}) \mathrm{O}_{4}$ tetrahedra having fully ordered $\mathrm{Al}$ and $\mathrm{Si}$ cations. Their structure consists of parallel sixmembered rings of alternating $\mathrm{AlO}_{4}$ and $\mathrm{SiO}_{4}$ tetrahedra (Grundy and Hassan 1982). The hexagonal symmetry (P63) results from the stacking of these sixmembered rings in an $\mathrm{ABAB}$... sequence. This stacking gives rise to large continuous channels parallel to the 63 axis and chains of smaller decahedral (eleven fold) cages along the threefold axes. The large channels contain extraframework cations $\left(\mathrm{Na}^{+}, \mathrm{Ca}^{2+}, \mathrm{K}^{+}\right)$, anions $\left(\mathrm{CO}_{3}{ }^{2-}, \mathrm{OH}^{-}\right)$, and $\mathrm{H}_{2} \mathrm{O}$ molecules whereas the undecahedral cages hold $\left[\mathrm{Na} \cdot \mathrm{H}_{2} \mathrm{O}\right]^{+}$clusters (Hassan and Grundy 1991; Hassan and Busseck 1992). This work aims at utilizing solid waste result from of aluminum sulfate industry as a source of silicate and alumina in the synthesis of some types of zeolites.

\section{MATERIALS AND METHODS}

partial De-aluminated kaolin (PDAK) is used as source of silica and alumina, the chemicals analysis of (PDAK) is shown in table (1) Aluminum sulfate is used as composite modifier for alumina ratio, sodium hydroxide is used as alkali media Table1. chemical of partial de-aluminate kaolin (PDAK). 
Table (1): Chemical analysis of raw, calcined and partial de-aluminated kaolin (PDAK), and zeolites (Chabazite and Cancrinite)

\begin{tabular}{|c|c|c|c|c|c|}
\hline $\begin{array}{c}\text { Sample (\%) } \\
\text { Parameter }\end{array}$ & $\begin{array}{c}\text { Raw } \\
\text { kaolinite }\end{array}$ & $\begin{array}{c}\text { Calcined } \\
\text { kaolinite }\end{array}$ & PDAK & Chabazite & Cancrinite \\
\hline \hline $\mathrm{SiO}_{2}$ & 49 & 55 & 85 & 52 & 36 \\
\hline $\mathrm{Al}_{2} \mathrm{O}_{3}$ & 34 & 39 & 6 & 23 & 29 \\
\hline $\mathrm{Fe}_{2} \mathrm{O}_{3}$ & 1 & 1.15 & 0.4 & 0.6 & 0.55 \\
\hline $\mathrm{TiO}_{2}$ & 2.7 & 3 & 3 & 5 & 3.5 \\
\hline $\mathrm{MnO}$ & 0.2 & 0.29 & $<0.2$ & - & - \\
\hline $\mathrm{CaO}$ & 0.21 & 0.24 & 0.08 & 0.11 & 0.13 \\
\hline $\mathrm{Na}$ & 0.18 & 0.23 & 0.01 & 12 & 24 \\
\hline $\mathrm{LOI}$ & 12.5 & 0.9 & 4.3 & - & 6.3 \\
\hline
\end{tabular}

\section{Synthesis of chabazite:}

Chabazite was obtained by hydrothermal synthesis in a stainless steel autoclave, Gel was prepared, by mixing $200 \mathrm{~g}$ of PDAK in $\mathrm{NaOH}$ solution (4 $\mathrm{M})$ at $130^{\circ} \mathrm{C}$ for $4 \mathrm{~h}$ under stirring conditions in plastic reaction beakers (1000 $\mathrm{ml}$ ) then $30 \mathrm{~g}$ of aluminum sulfate was added, and autoclaved at $2.5 \mathrm{~atm}$ pressure for $6-8 \mathrm{~h}$, the aging step was applied to the gel at $70{ }^{\circ} \mathrm{C}$ for $36 \mathrm{~h}$ and the reactions of zeolitization occurred without agitation. Subsequently, he product of the process was washed by distilled water up to $\mathrm{pH} \mathrm{9,} \mathrm{and} \mathrm{then}$ subjected to drying at $100^{\circ} \mathrm{C}$ for 24 hours.

\section{Synthesis of Cancrinite:}

The zeolitic material (Cancrinite) was obtained by hydrothermal synthesis in a stainless steel autoclave. The synthesis of gel was done by mixing $50 \mathrm{~g}$ of de-aluminated kaolin (PDAK) in $\mathrm{NaOH}$ solution (4M) at $130^{\circ} \mathrm{C}$ for $4 \mathrm{~h}$ under stirring conditions in plastic reaction beakers $(250 \mathrm{ml})$ then filtration and $5 \mathrm{~g}$ of aluminum sulfate was added to the filtrate, and autoclaved at $2.5 \mathrm{~atm}$. pressure for $6-8 \mathrm{~h}$, the aging step was applied to the gel 
at $70{ }^{\circ} \mathrm{C}$ for $36 \mathrm{~h}$ and the reactions of zeolitization occurred without agitation then, the product was washed by distilled water up to $\mathrm{pH}$ 9, and dried at 100 ${ }^{\circ} \mathrm{C}$ for 24 hours.

\section{Results and Discussion:}

The calcination and de-alumination of kaolinite resulted in formation of partially de-aluminated kaolinite (PDAK). The table (1) shows that PDAK contains silica and alumina with a ratio 14:1. The calcinations process of raw kaolinite before de-alimination deforms the Chrystal structure and transforms the raw kaolinite to more reactive phase (meta-kaolinite). (Ajayi, et al, 2012) as shown in the XRD of raw kaolinite and calcined kaolinite (Fig 1, 2). Upon acidification with sulphuric acid alumina is leached and aluminum sulphate is formed. The ratio of Silica /Alumina is adjusted using aluminum sulphate as a source of alumina to make the ratio 2.2: 1 The iron and potassium oxide in PDAK promote the formation of zeolite (Murat et al, 1992).

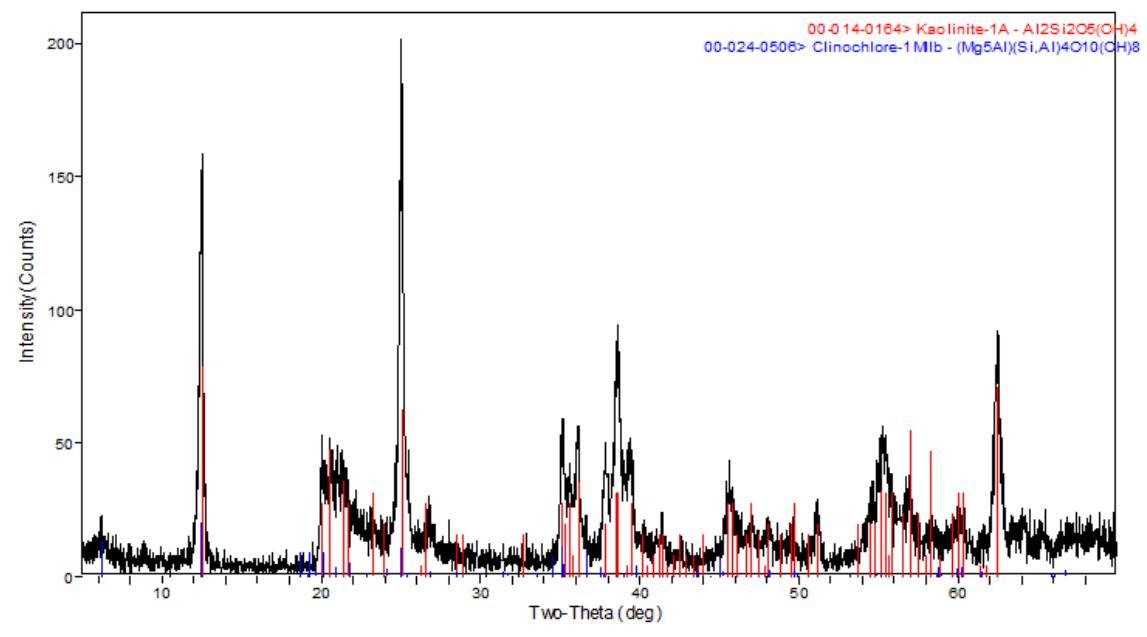

Fig. 1 Raw kaolinite 


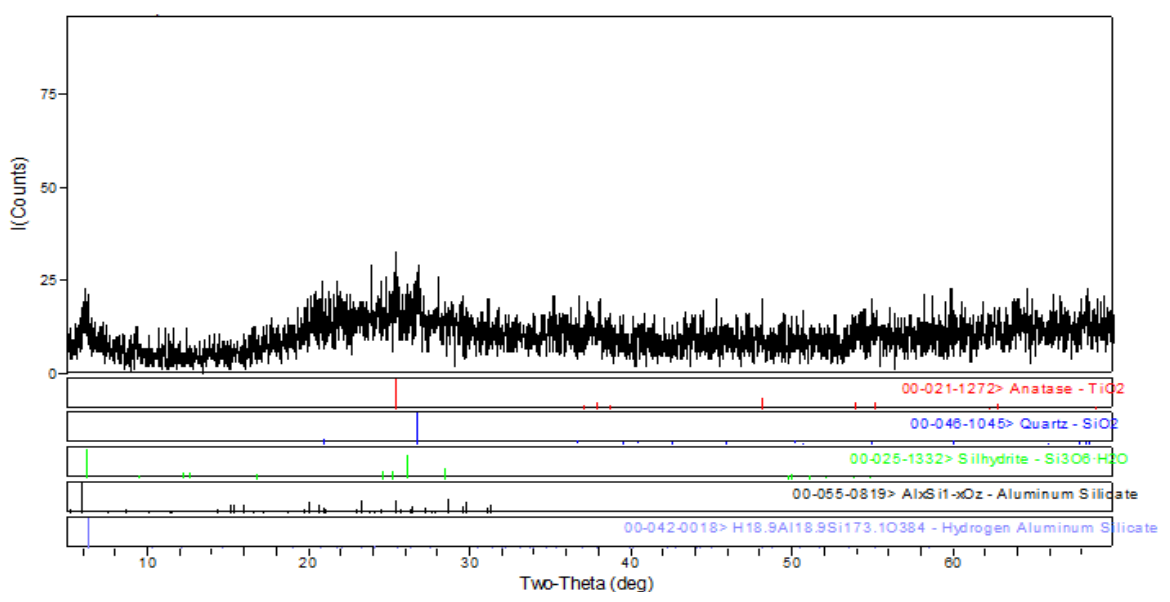

Fig. 2 Calcined kaolinite (meta-kaolinite)

\section{Characterization of the products:}

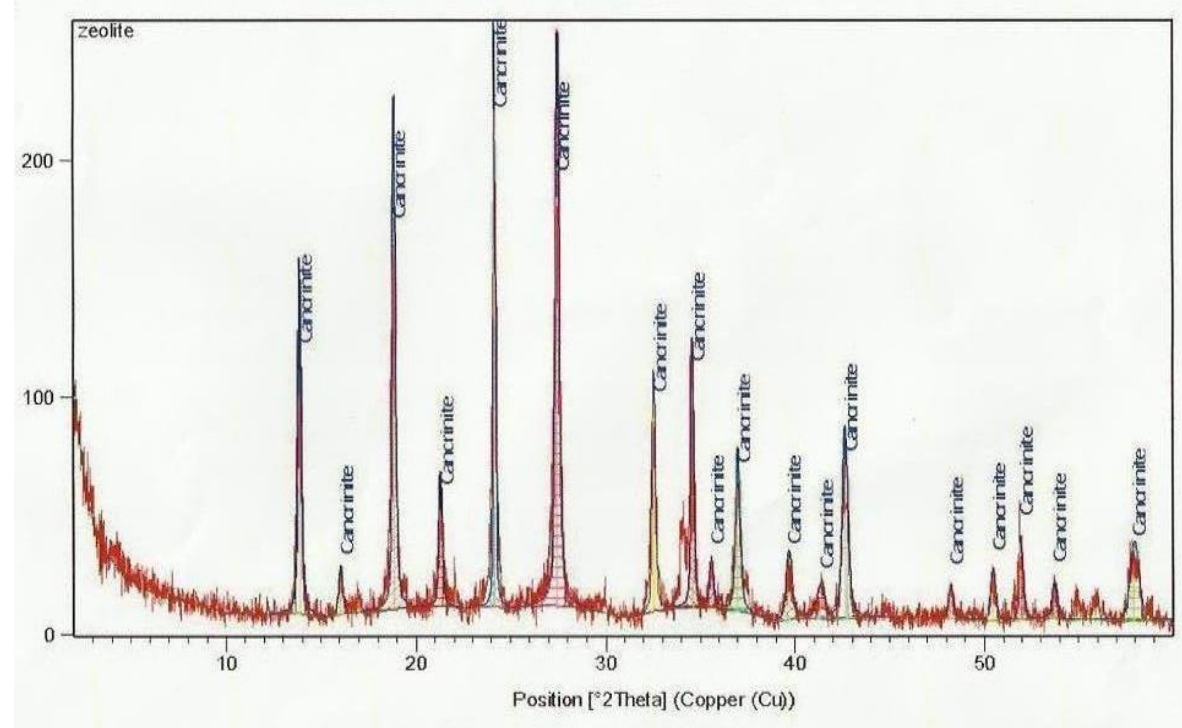

Fig. 3 XRD result of cancrinite 
The starting material and the synthesized products were analyzed using $\mathrm{X}$-ray diffraction (XRD), XRD was performed on X-ray diffraction equipment model $\mathrm{X}$ Pert PRO with Monochromator, $\mathrm{Cu}$-radiation $(\lambda=$ $1.5406 \AA$ ) at $50 \mathrm{kV} .40 \mathrm{~mA}$ and scanning speed $0.02 \% \mathrm{sec}$ were used. The reflection peaks between $2 \Theta=2^{\circ}$ and $60^{\circ}$, corresponding spacing $(\mathrm{d}, \AA)$ and relative intensities $\left(\mathrm{I} / \mathrm{I}^{\circ}\right)$ were obtained.

\section{Characterization of cancrinite:}

XRD pattern of cancrinite (Fig. 3) confirms synthesis of pure cancrinite without need for structure direction agents. Cancrinite is identified by its characteristic X-ray diffraction peaks at the following table :

Table (2): XRD Peak list of Cancrinite

\begin{tabular}{|c|c|c|c|}
\hline Pos.[ $\left.{ }^{\circ} \mathbf{2 T h}\right]$ & $\begin{array}{c}\text { FWHM } \\
\text { Left }\left[{ }^{\circ} \mathbf{2 T h}\right]\end{array}$ & d-spacing & Rel.Int. [\%] \\
\hline 13.8702 & 0.1968 & 6.38484 & 48.95 \\
16.0314 & 0.2362 & 5.52863 & 6.76 \\
18.8703 & 0.1771 & 4.70281 & 72.85 \\
21.3022 & 0.1968 & 4.17110 & 19.24 \\
24.1649 & 0.0984 & 3.68307 & 100.00 \\
27.4593 & 0.2362 & 3.24822 & 81.98 \\
32.5356 & 0.1574 & 2.75210 & 38.70 \\
34.5605 & 0.1574 & 2.59534 & 44.04 \\
35.5625 & 0.2362 & 2.52448 & 7.53 \\
36.9642 & 0.2362 & 2.43191 & 24.38 \\
39.6750 & 0.3149 & 2.27178 & 9.92 \\
41.3357 & 0.4723 & 2.18427 & 4.80 \\
42.6186 & 0.3149 & 2.12144 & 28.19 \\
48.2096 & 0.2362 & 1.88767 & 5.29 \\
50.4333 & 0.2362 & 1.80953 & 8.68 \\
51.9246 & 0.1574 & 1.76101 & 15.40 \\
53.7054 & 0.0 .2362 & 1.70675 & 5.99 \\
57.9019 & 0.4723 & 1.59265 & 11.49 \\
\hline
\end{tabular}




\section{Characterization of chabazite:}

Formation of zeolite chabazite phase was verified by XRD analyses. Since zeolite chabazite belongs to the CHA-type zeolite family, characteristic peaks associated with the CHA phase should be identified in the XRD pattern (assigned as CHA in Fig. 4). X ray diffraction patterns for the chabazite seeds are shown in Fig. 4. As it is clearly seen, pure zeolite chabazite crystals were synthesized using the developed synthesis procedure. Fig.5 also illustrates SEM micrograph of as-synthesized chabazite zeolite seeds. As it is observed, the crystal structure of chabazite zeolite is dish-shape. the crystal habits of chabazite zeolite is either multifaceted or hexagonal platelets. The crystal size of zeolite chabazite is estimated by DLS (Dynamic of light. Scattering) observations. As shown in Fig. 5, chabazite crystal sizes are in the range of 300-1000nm

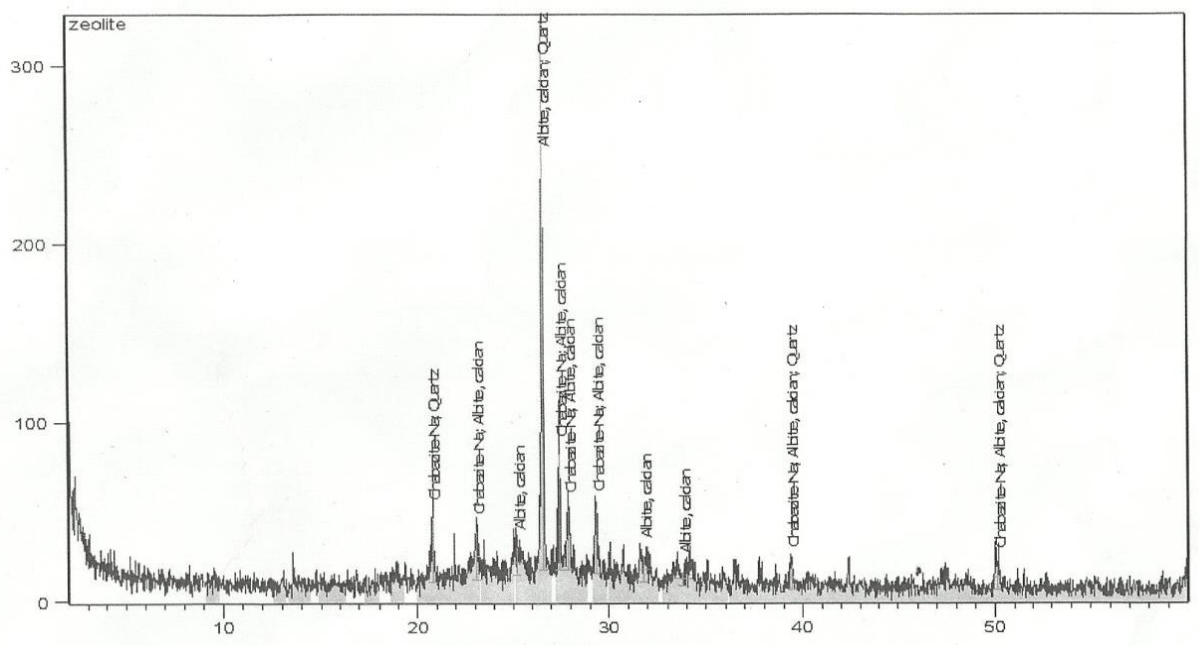

Fig. 4 XRD result of chabazite 
In accordance with XRD data (Fig. 4), The quartz and albite associated with chabazite the system Chabazite is identified by its characteristic X-ray diffraction peaks, in the following table:

Table (3): XRD Peak list of Chabazite

\begin{tabular}{|c|c|c|c|}
\hline Pos. $\left[{ }^{\circ} \mathbf{2 T h}\right]$ & $\begin{array}{c}\text { FWHM } \\
\text { Left }\left[{ }^{\circ} \mathbf{2 T h}\right]\end{array}$ & d-spacing & Rel.Int. [\%] \\
\hline 20.8058 & 0.1181 & 4.26948 & 11.60 \\
23.0877 & 0.2362 & 3.85241 & 8.48 \\
25.2142 & 0.6298 & 3.53213 & 4.81 \\
26.5613 & 0.0590 & 3.35597 & 100.00 \\
27.3910 & 0.0787 & 3.25617 & 20.83 \\
27.8504 & 0.1968 & 3.20349 & 10.71 \\
29.3368 & 0.1574 & 3.04448 & 11.78 \\
31.7909 & 0.4723 & 2.81485 & 4.61 \\
33.7787 & 0.9446 & 2.65361 & 2.63 \\
39.3814 & 0.2362 & 2.28804 & 4.44 \\
50.1371 & 0.4723 & 1.81952 & 4.47 \\
\hline
\end{tabular}

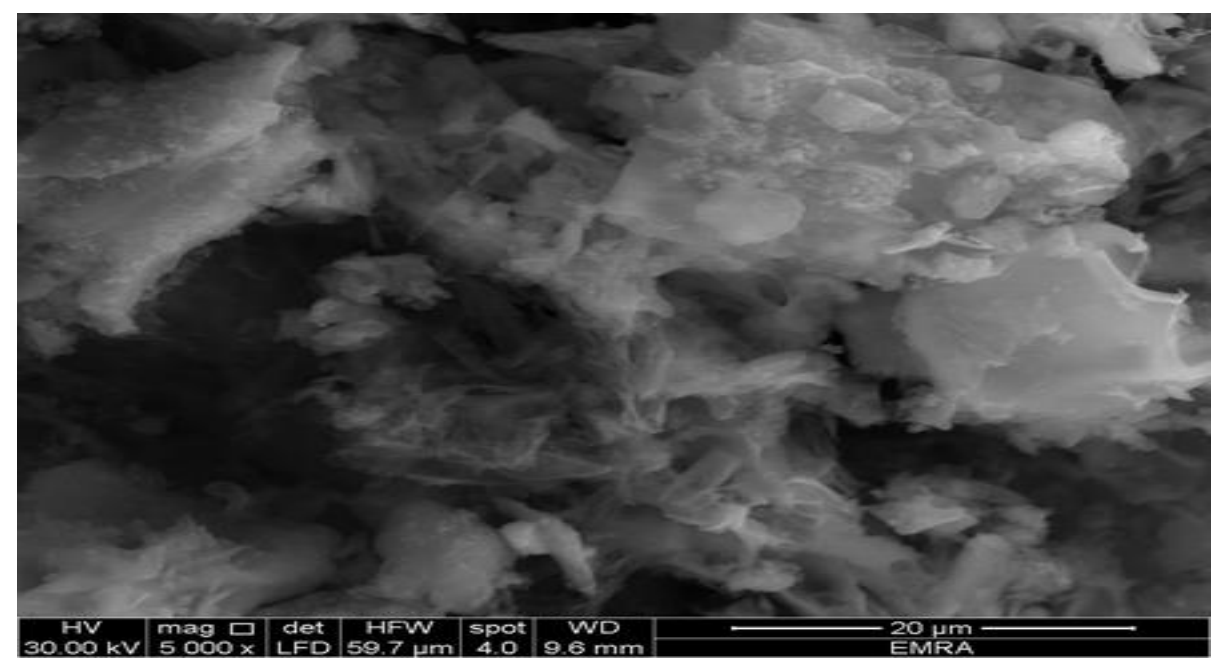

Figure 5. SEM Micrographs of Chabazite 

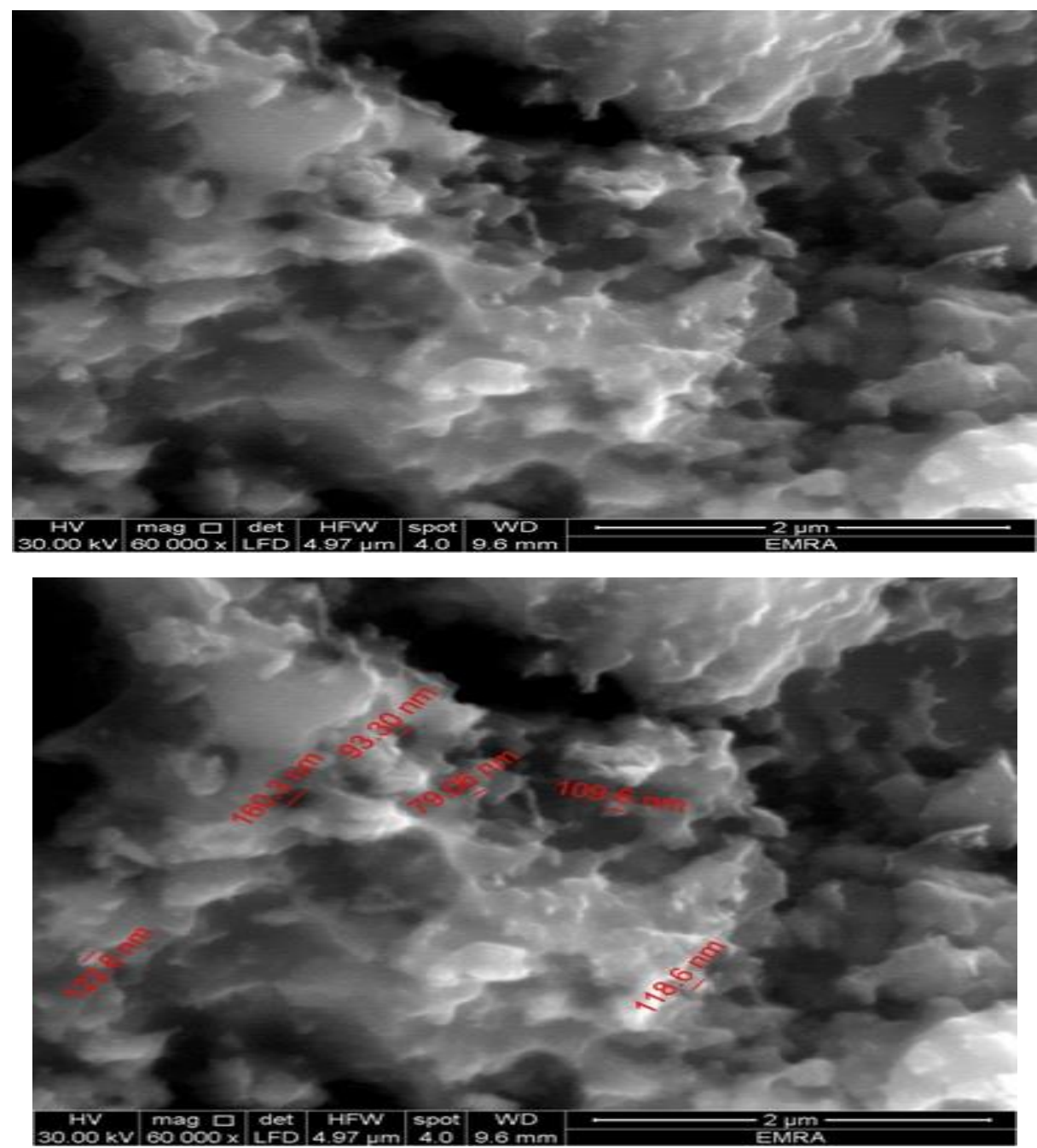

Figure 5. SEM Micrographs of Chabazite

\section{Uses Chabazite in removal ammonia:}

Ammonia removal by chabazite depends upon various factors such as, contact time, $\mathrm{pH}$, initial ammonium load. ammonia removal was faster at initial contact time because of empty adsorption site and a high concentration gradient. the experimental set up performed best at neutral $\mathrm{pH}$ range,the 
J. Environ. Sci.

Institute of Environmental Studies and Research - Ain Shams University

adsorption capacity of chabazite increased with an increase in initial concentration of ammonia.

\section{CONCLUSIONS}

For improved environmental protection, it is becoming increasingly important to find new, promising ways to use wastes such the solid waste obtained in aluminium sulphate manufacturing. The synthesis of zeolites from this type of waste material is justified as the waste, whose disposal constitutes an environmental issue. Furthermore, materials with advantageous ion exchange and adsorption properties such as Cancrinite and Chabazite can be manufactured for using in environmental technologies such as the removal of ammonium ions from drinking water. This approach makes this means environmentally and economically feasible for production of synthetic zeolites.

The synthesis reactions that were carried out have shown that, depending on the synthesis conditions of the process (i.e., $\mathrm{NaOH}$ concentration and reaction temperature), several types of zeolites with different channel system sizes can be obtained.

\section{REFERENCES}

Adamczyk, Z., and Bialecka, B. (2005), Hydrothermal synthesis of zeolites from polish coal fly ash. Pol. J. Environ. Stud. 14 (6), 713-719.

Ajayi, O. A., Abdulaziz A., O., Abdulkareem S. A., Mku. T., I, and Sam S. A. (2012), "Synthesis of Zeolite from Faujasite: Effects of Postsynthesis Aging and In situ seeding", Chemical and Process Engineering Research, ISSN 2224-7467, paper ISSN 22225-0913, Vol. 3. 
Barrer, R. M. (1945),Separation of mixtures using zeolites as molecular sieves. I. Three classes of molecular - sieve zeolite .J. Soc. Chem. Ind., 64 130.

Bekkum, V.H., Flanigen, E.M., Jacobs, P.A., and Jansen, J.C., (1991), Indruction to Zeolite Science and Practice, 2nd Revised End., Elsevier, Amsterdam, 13-34.

Breck, D.W. (1974)," Zeolitic Molecular Sieves ". New York: Wiley, New York, (1974) (Chapters 1 and 2).

Dyer, A., and Zubair, M. (1998), Ion-exchange in chabazite. Micro-porous and Meso-porous Materials, 22, 135-150.

Engelhardt, G., and Michel, D., (1987), " High-Resolution Solid-State NMR of Silicates and Zeolites". Wiley, New York.

Earl, D.J., and Deem, M.W., (2006), Toward a database of hypothetical zeolite structures. Ind. Engineering Chem. Res. 45, 5449-5454.

Georgiev, D., B. Bogdanov, Y. Hristov, I. Markovska, S. (2011), Synthesis of $\mathrm{Na}$ Zeolite from Natural Kaolinite, Oxidation Communications, 34, No 4, 812-819.

Grundy, H.D. and Hassan, I. (1982), The crystal structure of carbonate rich cancrinite. Canadian Mineralogist, 20, 239-251.

Hassan, I. and Grundy, H.D. (1991), The crystal structure of basic cancrinite, ideally $\mathrm{Na} 8[\mathrm{~A} 16 \mathrm{Si} 6 \mathrm{O} 24](\mathrm{OH}) 2 \cdot 3 \mathrm{H} 2 \mathrm{O}$. Canadian Mineralogist, 29, 377-383.

Hassan, I. and Buseck, P.R. (1992), The origin of the superstructure and modulations in cancrinite. Canadian Mineralogist, 30, 49-59.

Ilao, M. C., Yamamoto, H., and Segawa, K., (1996),"Shape-Selective Methylamine Synthesis over Small-Pore Zeolite catalysts," J. Catal.161, 20-30.

Loewenstein ,W. (1954), The distribution of aluminum in the tetrahedra of silicates and aluminates, Am. Mineral., 39- 92-96.

McCusker, L.B., Baerlocher, C., H., Flanigen, E.M., Jacobs, P.A., and Jansen, J.C. (2001), Introduction to zeolite science and practice Studies 
in Surface Science and Catalysis, vol. 137. Elsevier, Amsterdam, pp. 37-65.

Murat, M., Amokrane, A., Bastide, J. P. and Montanaro, L. (1992), "Synthesis of zeolites from thermally activated kaolinite, Some observations on nucleation and growth. Clay minerals, 27, 119130.

Querol, F. P., Alastuey, A. (1997), Synthesis of Na-zeolites from fly ash Fuel, 76 pp. 793-799

Rios, C.A., Williams, C.D., and Maple, M.J., (2007), "Synthesis of zeolite and zeo-types by hydrothermal transportation of kaolinite and meta-kaolinite". BISTUA 5 (1), 15-26.

Szoztak, R.S.,( 1998), Molecular Sieves: Principles of Synthesis and Identification (2nd ed.), Blackie Academic and Professional, London $359 \mathrm{pp}$

Sandoval, M.V., Henao, J.A., Rios, C.A., Williams, C.D., and Apperley, D.C., (2009), "Synthesis and characterization of zeotype ANA framework by hydrothermal reaction of natural clinker". Fuel $88,272-281$.

Saija, L.M., Ottana, R., and Zipelli, C., (1983), "Zeolitization of pumice in ash-sodium salt solutions". Mater. Chem. Phys. 8, 207-216.

Takaishi, T., Kato, M. and Itabashi, K., (1995), "Determination of the ordered distribution of aluminum atoms in a zeolitic framework". Part II. Zeolites 15, 21-32.

Tanaka, H., Miyagawa, A., Eguchi, H. and Hino, R., (2004), "Synthesis of apure-form Zeolite A from coal fly ash by dialysis". Ind. Eng. Chem. Res. 43, 6090-6094.

Walek, T.T., Saito, F.and Zhang, Q., (2008), "The effect of low solid/liquid ratio on hydrothermal synthesis of zeolites from fly ash. Fuel 87 ,

3194-3199.

Wang, L.J.and Sun, X.Y., (2008), "Influence of $\mathrm{NaOH}$ concentrations on synthesis of pure-form zeolite A from fly ash using two-stage method". J. Hazard. Mater. 155, 58-64. 


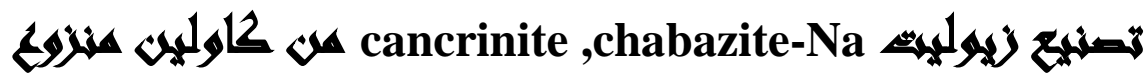

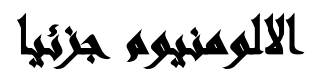

[r]

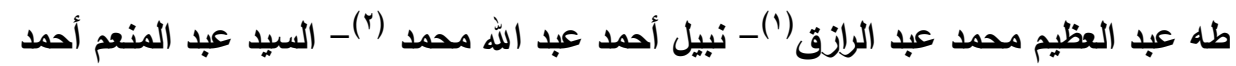

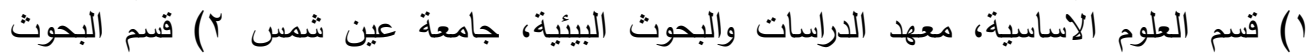
والتطوير ، شركة الثبة المصرية

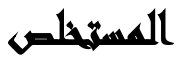

المخلفات الناتجة من صناعة كبريتات الالومنيوم تستخدم كمصدر للسليكا والالومنيوم. هذه الأه

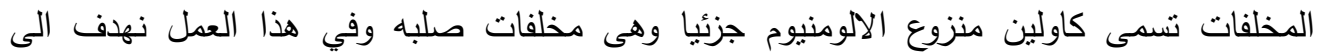

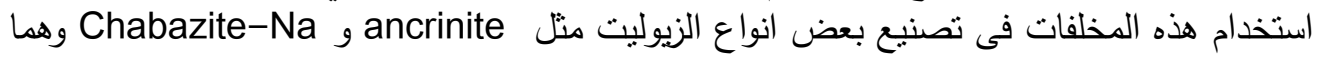

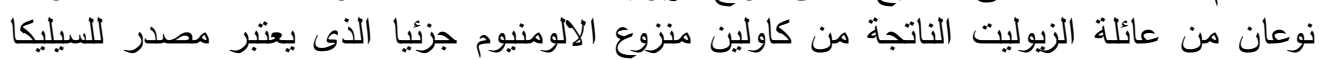
والالومنيوم ونسبة الالومنيوم يمكن ضبطها بإضافة كبريتات الالومنيوم-Cancrinite. Chabazite,

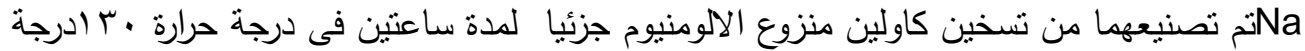

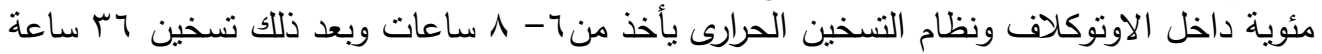

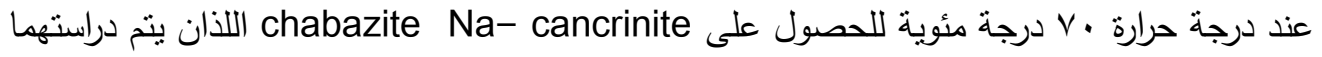
عن طريق حيود الاشعة السينية والميكروسكوب الإلكتروني. 